\title{
EXTENT OF THE NORTHERN BALTIC SEA DURING THE EARLY PALAEOZOIC ERA - NEW EVIDENCE FROM OSTROBOTHNIA, WESTERN FINLAND
}

\author{
ANNELI UUTELA
}

\begin{abstract}
UUTELA, ANNELI 1998. Extent of the northern Baltic Sea during the Early Palaeozoic Era - new evidence from Ostrobothnia, western Finland. Bulletin of the Geological Society of Finland 70, Parts 1-2, 51-68.

This study reports new evidence of the extent of the northern Baltic Sea during the Cambrian and Ordovician periods. A drillcore (DC304) from the Lappajärvi impact crater, western Finland, and erratics from the surrounding area were studied for acritarchs. The acritarchs from the drillcore were reworked by the explosion but indicate, however, that the Baltic Sea extended beyond the western coast of central Finland during the Lower Cambrian Vergale and the Middle Cambrian Kibartai regional stages as well as during Middle Ordovician transitions from Aseri to Lasnamägi and from Idavere to Jõhvi regional stages.

The provenance of the erratics was the Bothnian Bay, further north than the Lower Palaeozoic deposits previously known in the Bothnian Sea. The age could be determinated by their acritarch composition which shows that the sea also covered Central Ostrobothnia during the Lower Ordovician Billingen and early Middle Ordovician Lasnamägi regional stages. The drillcore samples contained also unknown spores. They suggest that there have been sediments and/or a terrestrial flora later than Ordovician in the Lappajärvi area.
\end{abstract}

Key words: microfossils, acritarchs, spores, sedimentary rocks, impact crater, erratics, Baltic Sea, Paleozoic, Cambrian, Ordovician, Lappajärvi, Alajärvi, Finland

Anneli Uutela, Geological Museum, P.O. Box 11, FIN-00014 University of Helsinki, Finland

\section{INTRODUCTION}

The previous estimations of the extent of the Baltic Sea during the Early Palaeozoic Era have been based on the drillcore and outcrop material from Denmark (Hansen 1945), Sweden (Hessland 195355, Thorslund 1960, Jaanusson 1972, 1982, Lindström 1979, Hagenfeldt 1989a) and Estonia (Öpik 1956, Männil 1966), and they suggest that the sea has occasionally covered the Bothnian Sea. In Finland only the Söderfjärden drillcore (Fig. 1) has been included in the estimations by Hagenfeldt (1989a).

According to seismic profiles, Early Palaeozoic, i.e. Cambrian and Ordovician, marine deposits cover large areas of the bottom of the Bothnian Sea (the southern part of the Gulf of Bothnia; Winterhalter 1972), and Cambrian deposits the 


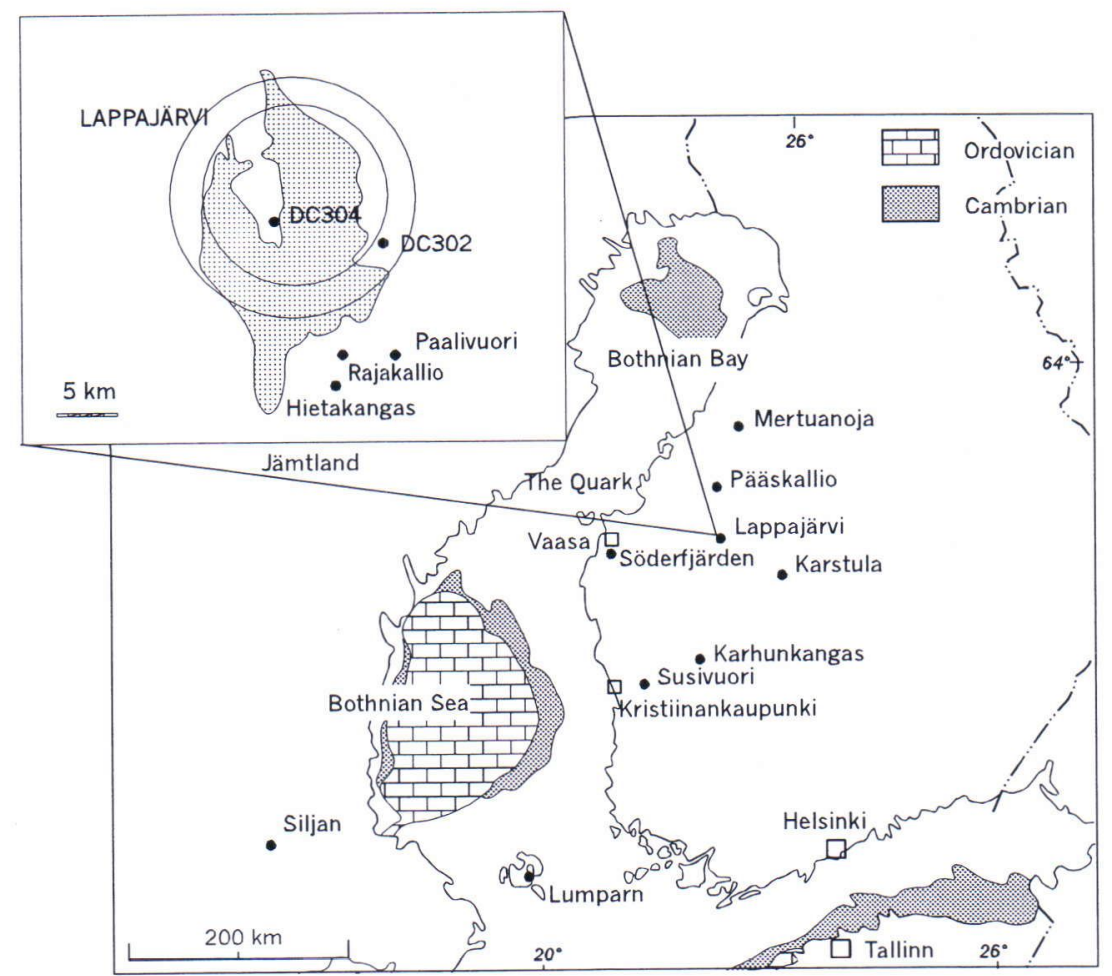

Fig. 1. Location of Lake Lappajärvi and the sites of the erratic boulders.

bottom of the Bothnian Bay (the northern part of the Gulf of Bothnia; Wannäs 1989; Fig. 1). Cambrian fissure fillings occur in the archipelagos of Åland (Bergman 1982) and southwestern Finland (Martinsson 1956, Simonen 1956).

In situ Cambrian sediments cover the Söderfjärden impact crater (Tynni 1978, 1982a, Hagenfeldt $1989 \mathrm{~b}, \mathrm{c})$, only $100 \mathrm{~km}$ west of Lake Lappajärvi (Fig. 1). Sandstone erratics - probably Cambrian in age - have been found in Karstula, Ostrobothnia (Simonen \& Kouvo 1955, Tynni 1974) and on the eastern coast of the Bothnian Bay (Uutela 1983). They show the Cambrian sea reached up to $65^{\circ} \mathrm{N}$.

Two drillcores from Finngrunden on the Swedish side of the southern Bothnian Sea contain Early Ordovician trilobites (Thorslund \& Axberg 1979, Tjernvik \& Johansson 1980). Thus far, the only known in situ Ordovician sedimentary deposits in Finland are situated at the bottom of
Lumparn Bay, Åland (Kulling 1926, Winterhalter 1972). Uutela (1989) found Cambrian and Ordovician erratic boulders in southwestern Finland up to $62^{\circ} \mathrm{N}$. Reworked Ordovician acritarchs have also been found in Quaternary deposits elsewhere in Ostrobothnia (Kujansuu \& Uutela 1997, Eriksson et al. in print).

The aim of the study was to investigate Palaeozoic acritarchs from a drillcore at Lappajärvi and from erratic boulders found in Ostrobothnia and to discuss the extent of the northern Baltic Sea during the Early Palaeozoic Era.

\section{THE AREA STUDIED}

Lappajärvi is located in Ostrobothnia, Central Finland (Fig. 1). It has a more than 150 year history of geological research: the first hundred years it was interpreted as a volcano (Eskola 1927), sin- 
ce 1968 as an impact crater (Svensson 1968). The diameter of the crater is $17 \mathrm{~km}$. The ${ }^{40} \mathrm{Ar}-{ }^{39} \mathrm{Ar}$ age of kärnäite is $77 \mathrm{Ma}$ (Jessberger \& Reimold 1980), and the palaeomagnetic age is less than $200 \mathrm{Ma}$ (Pesonen et al. 1984). In drillcore DC302 from the eastern slope of the crater beneath the Quaternary tills, there are 18 metres of sedimentary rocks with Precambrian acritarchs (Uutela 1990).

\section{MATERIAL AND METHODS}

The drillcore material (DC304) studied comprises 12 samples of mudstone with acritarchs from the Kärnänsaari island three kilometres southwest of the geometrical centre of the crater. Mudstone at a depth of $32.60-35.20 \mathrm{~m}$ is overlain and underlain by suevite and impact breccia material (Fig. 2).

Microfossils of erratic boulders were also studied, as were acritarchs in erratic boulders found in Ostrobothnia. Two boulders of reddish marl and one yellowish Baltic limestone (calcilutite) are from the Hietakangas esker in Höykkylä, Alajärvi (map sheet 2313 08, $\mathrm{x}=6992.10, \mathrm{y}=2485.90$, $\mathrm{z}=105$ ). One greenish marl is from the Rajakallio esker and littoral deposit complex in Höykkylä (2313 08, $x=6996.50, y=2488.06, z=125$ ). One reddish marl is from the Paalivuori littoral deposit in Hoisko, Alajärvi (2313 11, $\mathrm{x}=6995.10, \mathrm{y}=$ $2494.60, \mathrm{z}=130$ ). All these sites are located 13$17 \mathrm{~km}$ southeast of Kärnänsaari. One erratic of reddish marl is from the Susivuori littoral deposit in Kristiinankaupunki (1232 12, $\mathrm{x}=6911.00$, $y=1535.00, z=120), 140 \mathrm{~km}$ southwest of Lappajärvi, and two from the Pääskallio littoral deposit in Kaustinen (2323 07, $\mathrm{x}=7049.30, \mathrm{y}=2487.45$, $\mathrm{z}=81$ ), $40 \mathrm{~km}$ north of Lappajärvi (Fig. 1).

Before the maceration process, samples were treated with $10 \% \mathrm{HCl}$ and washed with distilled water to prevent contamination by modern pollen and spores. In the maceration process $\mathrm{HCl}$ and $\mathrm{HF}$ were used before filtering the residue (Vidal 1988). The sample size of mudstone was ca. $20 \mathrm{~g}$ and of limestone $50 \mathrm{~g}$.

The acritarchs studied here are rather poorly preserved. Many specimens of the Ordovician gen-

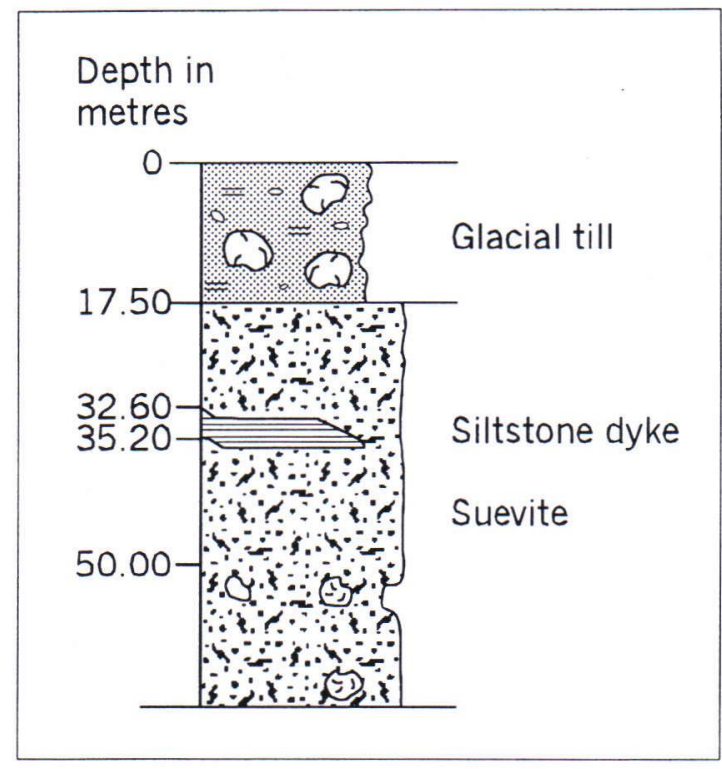

Fig. 2. The sequence of the upper part of the Lappajärvi drillcore DC304.

era Baltisphaeridium and Ordovicidium are therefore impossible to identify on the species level. Species of the genus Leiosphaeridia are excluded from the percentile proportions due to their minimum dating value.

In this study the terms for Estonian regional stages of the Cambrian and Ordovician systems are used because the main reference material of acritarchs is from Estonia. In Estonia, the Ordovician system is subdivided into 19 regional stages, and the Cambrian into eight (Fig. 3).

\section{RESULTS}

\section{Acritarchs in the Kärnänsaari drillcore DC304}

In the miscellaneous assemblage of microfossils in the Lappajärvi drillcore, $75.4 \%$ are Cambrian and $21.1 \%$ Ordovician acritarchs, in addition to $3.5 \%$ trilete spores of unknown age. The maximum Cambrian specimens occur at a depth of $33.50 \mathrm{~m}$, Ordovician at a depth of $35.00 \mathrm{~m}$ and spores at a depth of $33.90 \mathrm{~m}$ (Table 1a \& b). 


\begin{tabular}{|c|c|c|}
\hline $\begin{array}{l}\text { ESTONIAN } \\
\text { REGIONAL STAGES }\end{array}$ & \multicolumn{2}{|c|}{ BRITISH SERIES } \\
\hline PORKUNI $F_{\text {II }}$ & \multirow{3}{*}{ ASHGILL } & \multirow{3}{*}{$\begin{array}{l}\text { UPPER } \\
\text { ORDOVICIAN }\end{array}$} \\
\hline PIRGU $F_{I} c$ & & \\
\hline VORMSI $F_{1} b$ & & \\
\hline NABALA $F_{I}$ I & \multirow{6}{*}{ CARADOC } & \multirow{10}{*}{$\begin{array}{l}\text { MIDDLE } \\
\text { ORDOVICIAN }\end{array}$} \\
\hline RAKVERE E & & \\
\hline OANDU $\mathrm{D}_{\mathrm{m}}$ & & \\
\hline KEILA $D_{\text {II }}$ & & \\
\hline JöHVI $D_{1}$ & & \\
\hline IDAVERE $C_{m}$ & & \\
\hline KUKRUSE $C_{\text {II }}$ & \multirow{4}{*}{ LLANVIRN } & \\
\hline UHAKU $C_{I} \mathrm{c}$ & & \\
\hline LASNAMÄGI $C_{1} b$ & & \\
\hline ASERI $C_{1}$ a & & \\
\hline KUNDA $B_{m}$ & \multirow{3}{*}{ ARENIG } & \multirow{6}{*}{$\begin{array}{l}\text { LOWER } \\
\text { ORDOVICIAN }\end{array}$} \\
\hline VOLKHOV $\mathrm{B}_{\text {II }}$ & & \\
\hline BILLINCEN $\mathrm{B}_{\mathrm{I}} \mathrm{b}$ & & \\
\hline HUNNEBERC $\mathrm{B}_{\mathrm{I}} \mathrm{a}$ & \multirow{3}{*}{ TREMADOC } & \\
\hline VARANGU $A_{m}$ & & \\
\hline PAKERORT $\mathrm{A}_{\mathfrak{n}}$ & & \\
\hline ULGASE & \multicolumn{2}{|c|}{ UPPER CAMBRIAN } \\
\hline PANERIAI & \multirow{3}{*}{\multicolumn{2}{|c|}{ MIDDLE CAMBRIAN }} \\
\hline KYBARTAI & & \\
\hline RAUSVE & & \\
\hline VERCALE & \multirow{4}{*}{\multicolumn{2}{|c|}{ LOWER CAMBRIAN }} \\
\hline TALSY & & \\
\hline LONTOVA & & \\
\hline ROVNO & & \\
\hline
\end{tabular}

Fig. 3. Cambrian and Ordovician Estonian regional stages. References: Mens et al. (1987) and Nõlvak (1997).

Kärnänsaari mudstone includes $1.32-5.35 \%$ $\mathrm{CaCO}_{3}$ (Table 1a). A large amount of $\mathrm{CaCO}_{3}$ does not indicate a large number of Ordovician acritarch species (correlation coefficient $\mathrm{R}=0.448$ ).

\section{Cambrian species}

Living ranges of Cambrian species are presented in Table 2; $8.9 \%$ of species are restricted to the Early Cambrian and $61.0 \%$ of species have a living range from the Early to Middle Cambrian.

Filisphaeridium molliculum (0.6\%; Fig. 4a) disappears in the Early Cambrian Vergale Regional Stage, where a living range of Helosphaeridium coniferum $(0.6 \%$; Fig. 4 b) is restricted. In addition to the southern Baltic Sea, F. molliculum is recorded at Söderfjärden (Hagenfeldt 1989b), $H$. coniferum is reported in Poland, Scotland, Spitzbergen and Canada (Moczydlowska 1991 and references therein), but this is the first time it has been recorded in the northern Baltic Sea. Liepaina plana and Micrhystridium notatum (totally $0.1 \%$ ) appear in the upper part of the Rausve Regional Stage during the Early Cambrian. These species are also reported at Söderfjärden (Hagenfeldt 1989b).

The only species restricted to the Middle Cambrian Kibartai Regional Stage is Baltisphaeridium pseudofoveolatum (0.06\%; Fig. 4c). It has been earlier reported in Sweden, Latvia, Lithuania and the Kaliningrad Region (Hagenfeldt 1989b and references therein).

\section{Ordovician species}

Living ranges of Ordovician species are presented in Table 3; $29 \%$ of species have a long living range from the Early to Late Ordovician, $9 \%$ of species have lived from the Early Ordovician to the early Middle Ordovician and $12.2 \%$ of species from the late Middle Ordovician to the Late Ordovician (Uutela \& Tynni 1991 and references therein).

Based on the preliminary results from the Männamaa material, Hiiumaa, the living range of $\mathrm{Pe}$ teinosphaeridium eximum (Fig. $4 \mathrm{~d}$ ) is restricted in the Volkhov $\left(B_{\text {II }}\right)$ to Aseri $\left(C_{I} a\right)$ regional stages in Estonia. In the early Middle Ordovician Lasnamägi Regional Stage $\left(\mathrm{C}_{\mathrm{I}} \mathrm{b}\right)$ Baltisphaeridium dasos, Ordovicidium grotlingboensis and $O$. nudum appear. Later in the Middle Ordovician, i.e. at the beginning of the Jõhvi Regional Stage $\left(D_{\mathrm{I}}\right)$, appears Cheleutochroa venosa (Fig. 4e). Other species with living ranges restricted to the late Middle Ordovician are Baltisphaeridium trabeculaespinae, Ordovicidium elegantulum, Veryhachium irroratum, V. reductum and V. trisulcum.

\section{Unknown spores}

The material includes two previously unknown types of spores.

Spore 1. The triangular amb has straight or slightly convex sides. Triletic sutures are straight, usually extending to the periphery of the spore. The thin exine $(0.5 \mu \mathrm{m})$ is scabrate or microgranulate. The length of side varies $20-30 \mu \mathrm{m}$, mean 

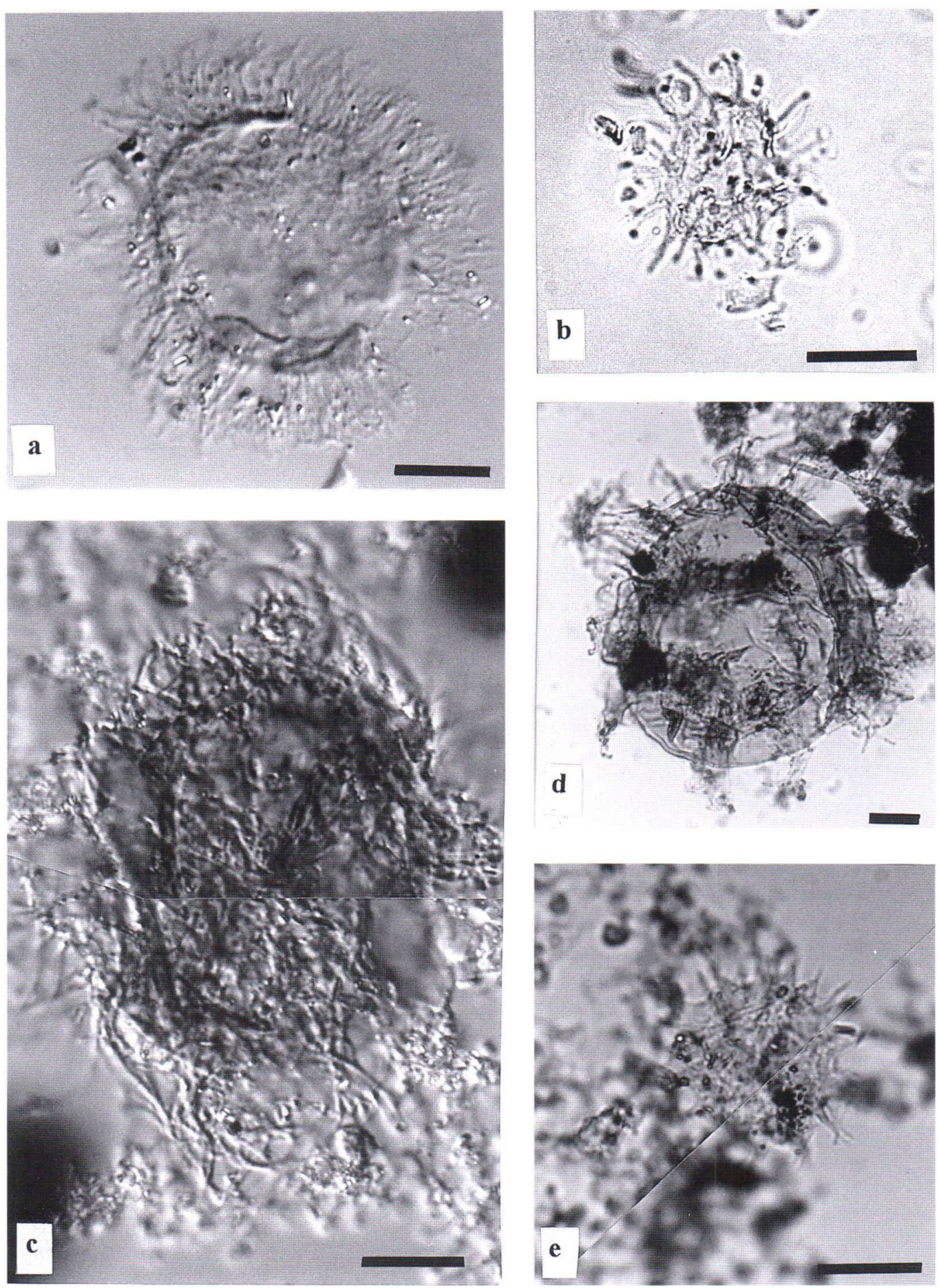

Fig. 4. Cambrian and Ordovician acritarchs in the Lappajärvi DC304: Filisphaeridium molliculum (a), Helosphaeridium coniferum $(b)$, Baltisphaeridium pseudofoveolatum $(c)$, Peteinosphaeridium eximum $(d)$ and Cheleutochroa venosa (e). Bar equals $10 \mu \mathrm{m}$. 
is $25 \mu \mathrm{m}$. A total of 74 specimens were recorded. Spore 1 resembles the modern spore of Pteridium (Figs. 5a-d).

Spore 2. The amb is triangular, sides are straight. Triletic sutures are straight, usually extending to the periphery of the spore. The rather thick exine $(1.5 \mu \mathrm{m})$ is microgranulate. The length of side is $22 \mu \mathrm{m}$. Only one specimen is recorded at the depth of $34.50 \mathrm{~m}$. Spore 2 resembles the modern spore of Sphagnum (Figs. 5e-f).

The oldest spores from the Precambrian deposits in Russia and Latvia have been reported by Volkova (1976), but instead of a defined trilete suture they have trilete folds. The terrestrial Ordovician spores reported by Vavrdová (1984) and the Silurian miospores reported by Richardson (1996) differ greatly from the spores 1 and 2 . Among the present assemblage $31 \%$ of acritarchs have a living range up to the Lower Silurian or later. Because real Silurian indicator species are missing, it seems improbable that Silurian deposits also covered the Lappajärvi area. Richardson (pers. comm.) thinks the spores are possibly postFrasnian (Upper Devonian) or later.

No pollen grains were found. This speaks against the contamination by modern material since pollen grains are more abundant than spores in modern deposits. Therefore it is probable that the spores were deposited when sporophytes had already developed but before the appearance of pollen producing plants, i.e. during the Carboniferous.

\section{The Lappajärvi area before the Quaternary ice age}

According to the results, the area where Lappajärvi is situated was covered with Lower Palaeozoic deposits before the meteorite impact. The lowermost deposits consisted of Lower Cambrian Vergale deposits overlying Middle Cambrian Kibartai deposits. Middle Cambrian Rausve deposits are possible, but not verified here. These were mixed during the explosion and fell down into a fissure filling of suevite.

The Ordovician acritarchs suggest that the sea covered the Lappajärvi area at least during the transitions from Aseri to Lasnamägi and from Idavere to Jõhvi regional stages, Middle Ordovician.

It seems that Precambrian deposits covered only the eastern side of Lappajärvi because the present assemblages lack the Precambrian specimens found by Uutela (1990) on the rim area of the Lappajärvi impact crater.

Although the two types of spores remain unidentified, they indicate that during an unknown period after the Ordovician, sediments containing spores have been deposited in the Lappajärvi area.

\section{Acritarchs of the Hietakangas erratic boulder}

Among the erratic boulders only the yellowish grey Baltic limestone (calcilutite) from the Hietakangas esker yielded 44 rather poorly preserved acritarch specimens. The assemblage is typical of the Baltic area; most of species belong to genera Baltisphaeridium and Ordovicidium (Table 4). Baltisphaeridium esthonicum (Fig. 6a) disappears in the Lasnamägi Regional Stage $\left(\mathrm{C}_{\mathrm{I}} \mathrm{b}\right)$, when $B$. parvigranosum (Fig. 6b), Ordovicidium grotlingboensis (Fig. 6c) and O. nudum (Fig. 6d) appear. Thus the age of the Hietakangas boulder is the Lasnamägi Regional Stage, early Middle Ordovician.

\section{Other limestone erratics}

Other limestone erratics contained no acritarchs. Oxidation has destroyed organic-walled fossils in reddish marl. Conodonts are better for dating this type of limestone (Löfgren 1985), but a larger sample size, more than $500 \mathrm{~g}$, would be needed. In the northern Baltic Sea the Finngrunden reddish marl is Arenig in age (Tjernvik \& Johansson 1980). It correlates with the Estonian regional stages of Billingen, Volkhov and the beginning of Kunda in Estonia. Based on lithological features the Hietakangas, Paalivuori, Pääskallio and Susivuori boulders of reddish marl are of the same age.

The age determination of the Rajakallio greenish marl boulder is complicated and remains unsolved. Deposits of greenish marl are found in the Rapla drillcore in the Middle Ordovician Jõhvi and Oandu regional stages (Põlma 1972, Uutela \& 

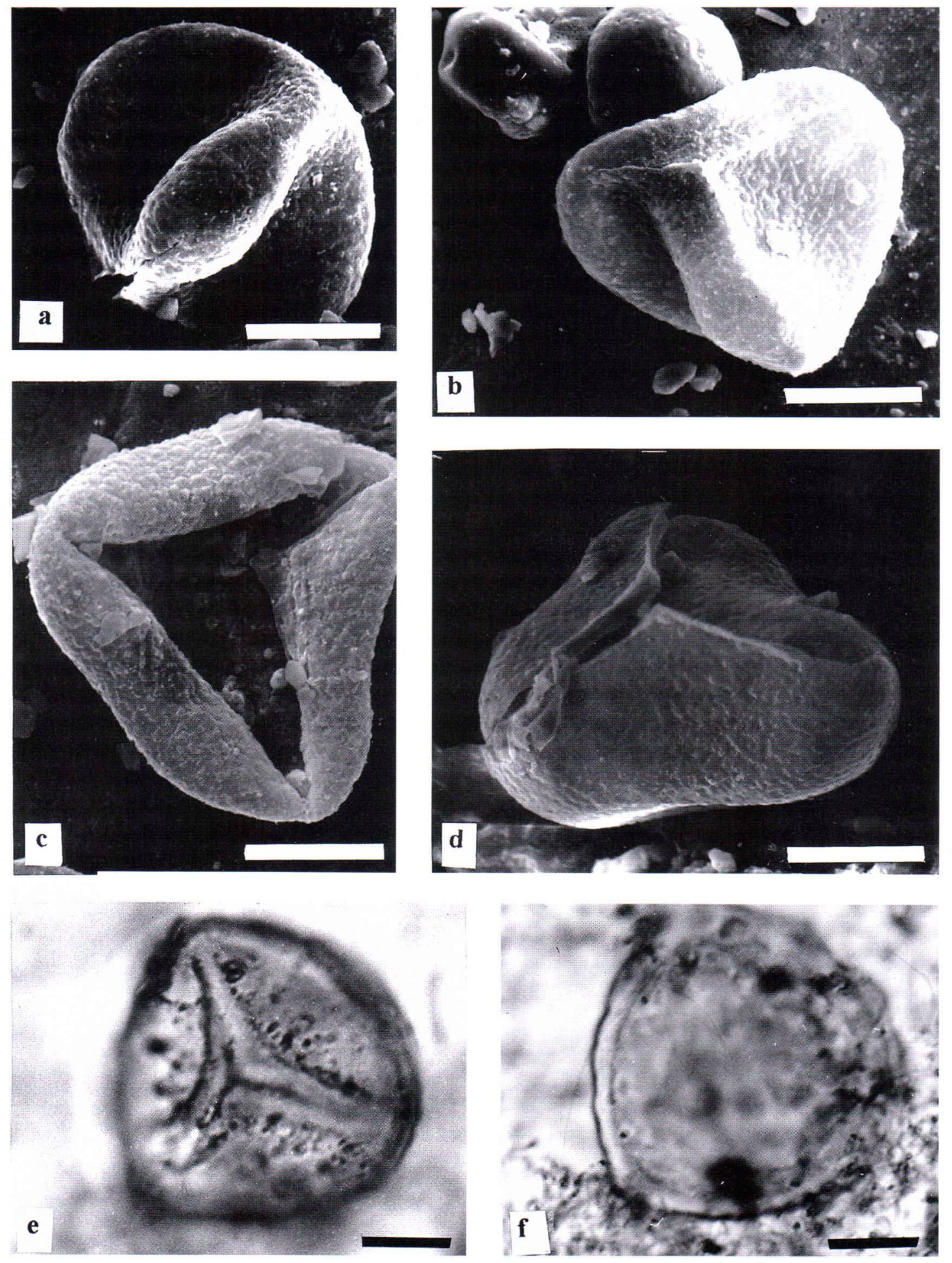

Fig. 5. Unknown spores in the Lappajärvi DC304. Spore 1 (a-d) and spore 2 (e-f). Bar equals $10 \mu m$. 

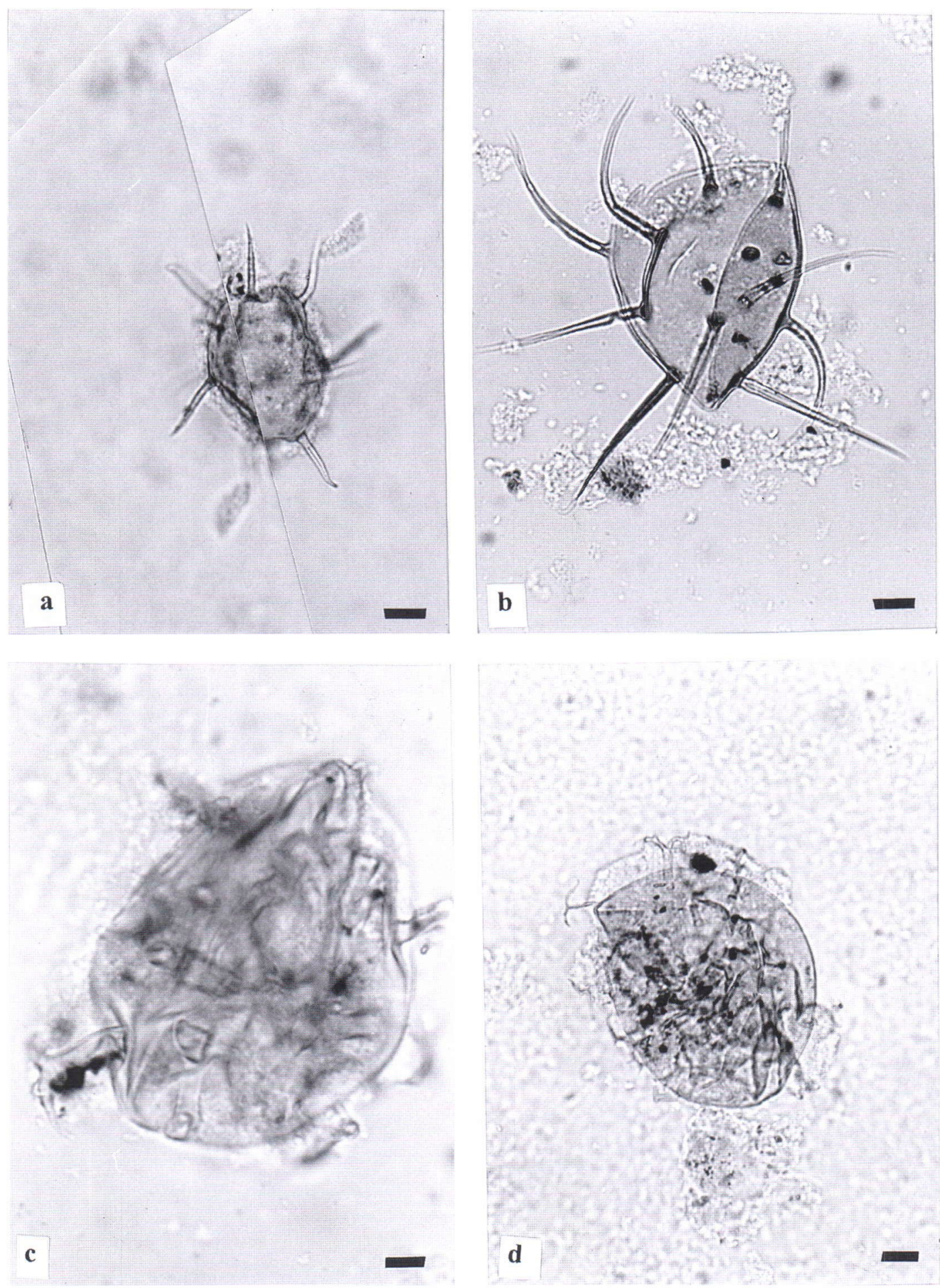

Fig. 6. Ordovician acritarchs in the Hietakangas erratic boulder. Baltisphaeridium esthonicum (a), B. parvigranosum (b), Ordovicidium grotlingboensis (c) and O. nudum (d). Bar equals $10 \mu \mathrm{m}$. 
Tynni 1991) and in the Männamaa drillcore from the Jõhvi to Vormsi regional stages, Middle to Upper Ordovician (Uutela in prep.). Greenish marl was also deposited in Estonia during the Early Silurian Juuru Regional Stage (Põlma 1972, Uutela \& Tynni 1991, Uutela in prep.). According to estimations by Männil (1966), greenish marl was deposited during the Lasnamägi to Idavere regional stages in the northern Baltic Sea.

\section{Provenance of the Ordovician limestone erratics}

As mentioned above, there are Ordovician in situ deposits at the bottom of the Bothnian Sea (Fig. 1). The northernmost border reaches $62^{\circ} 40^{\prime} \mathrm{N}$, like at Kristiinankaupunki, and the westernmost side reaches near $20^{\circ} 00^{\prime} \mathrm{E}$ (Winterhalter 1972). Because of the glacial movement from the northwest, this area is not a possible provenance of the Ostrobothnian boulders.

The meteorite impacted a large area of sedimentary deposits in the surroundings of the present lake of Lappajärvi. Because of the lack of acritarchs, it is impossible to verify if the provenance of the boulders of reddish marl from Hietakangas and Paalivuori, as well as the Rajakallio greenish marl boulder are near this area. The location of the Pääskallio boulder indicates that the provenance of boulders of reddish marl found there is more northern than the Lappajärvi area (Fig. 1). The Hietakangas boulder of calcilutite seems to be from the similar deposits that covered the Lappajärvi area. In the Lappajärvi - Kaustinen area the latest advancement of the continental ice has taken place from the northwest (Mölder 1948, Geological Survey of Finland 1986).

The provenance of the reddish marl from Susivuori is possibly different from that of the other boulders, because in the Kristiinankaupunki area the continental ice flow came from the north (Mölder 1948, Geological Survey of Finland 1986).

Reworked Ordovician acritarchs from Kauhajoki may be from the same provenance, i.e. from the Quark or the Bothnian Bay (Kujansuu \& Uutela 1997). Reworked Ordovician acritarchs found in Eemian deposits at Mertuanoja (Eriksson et al. in print) suggest that there may have been Lower Palaeozoic deposits as far north as at the bottom the Bothnian Bay. The acritarch assemblage of Mertuanoja indicates deposits of the Lasnamägi Regional Stage (Baltisphaeridium parvigranosum).

\section{DISCUSSION AND CONCLUSIONS}

\section{The extent of the Cambrian sea in the north- ern Baltic Sea}

For Hessland (1955), the extent of the northern part of the Baltic Sea remained an unsolved question. According to Öpik (1956), the sea covered the Bothnian Sea and the Bothnian Bay at the beginning of early Cambrian. This occurred during the Vergale Regional Stage and at the beginning of the Rausve Regional Stage (late Early Cambrian), but not as late as at the end of the Rausve Regional Stage (Hagenfeldt 1989a). The results of the acritarch analysis in this study support these results with a wider eastern extent, however (Fig. 7).

Hansen (1945) and Thorslund (1960) suggested that the early and late Middle Cambrian Baltic Sea reached only to southeastern Sweden, Denmark and western Norway. The presence of Baltisphaeridium pseudofoveolatum in this study - although only one specimen - indicates that the sea did reach up to the Lappajärvi area during the early Middle Cambrian Kibartai Regional Stage, a similar result as reported by Hagenfeldt (1989a), except a wider eastern extent (Fig. 7). Late Middle Cambrian acritarchs (the Paneriai Regional Stage) were not found in this material. This supports the theory of Hagenfeldt (1989a) that the sea covered the Bothnian Sea, but not the western coast of Finland. Thus, the Lappajärvi area was dry land during the late Middle Cambrian.

\section{The extent of the Ordovician sea}

At least two different types of Ordovician acritarch assemblages can be distinguished in the Lappajär- 


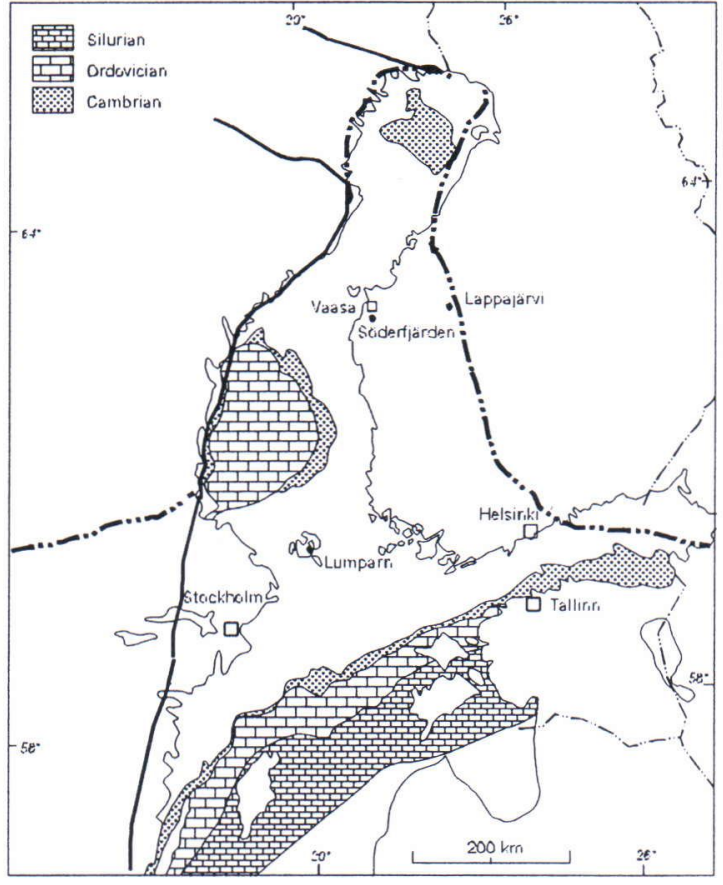

Fig. 7. Extent of the Lower (whole line) and early Middle Cambrian Baltic Sea (dashed line), the Swedish side of the sea is according to Hagenfeldt (1989a).

vi material. The older one is from the transition of the Aseri $\left(C_{T} a\right)$ to Lasnamägi $\left(C_{T} b\right)$ regional stages (early Middle Ordovician). The more recent one is from the transition of the Idavere $\left(\mathrm{C}_{\mathrm{III}}\right)$ to Jõhvi $\left(D_{I}\right)$ regional stages (middle of Middle Ordovician). Age determinations of erratic boulders indicate that during the Billingen - Kunda (reddish marl) and Lasnamägi (yellowish calcilutite) regional stages, the Ordovician sea covered the northern Bothnian Sea.

According to Thorslund (1960), the Early Ordovician (Early Tremadocian, i.e. Pakerort Regional Stage) sea extended only to the southern coast of Finland. Männil (1966) estimates that during the Pakerort Regional Stage $\left(\mathrm{A}_{\mathrm{II}}\right)$ quartzrich sand was deposited in the central Baltic Sea. Deposits of Dictyonema shale in situ, Pakertort in age in the Siljan district, Central Sweden (Jaanusson 1982) speaks against both theories.
According to Männil (1966), during the Late Tremadoc (i.e. Varangu Regional Stage) and Arenig to early Llanvirn (i.e. Hunneberg, Volhov, Kunda and Aseri regional stages; $B_{I I}-C_{I} a$ ) only the eastern Bothnian Sea was covered with oceanic waters and yellowish grey Baltic limestone (calcilutite), and reddish and greenish marls were deposited. In situ deposits of these ages in the Siljan district and further north in Jämtland (Jaanusson 1982) also contradicted Männil's theories. According to Lindström (1979), during the Arenig the sea covered wide areas of southern Finland, and Thorslund (1960) interpreted the sea as extending north to western Finnish Lappland. The present material, especially the erratic boulders of reddish marl, suggest that the Early Ordovician sea reached out to the Bothnian Bay (Fig. 8) and thus supports the theories of Thorslund (1960) and Lindström (1979). One of the Ordovician transgressions in Europe took place during the transition of Tremadoc to Arenig (Fortey 1984), in the Estonian regional stages it took place during the Varangu and Billingen regional stages. Based on this evidence, the reddish marl is deposited during the Billingen Regional Stage, instead of Billingen - Kunda (cf. p. 56).

During the Middle Ordovician Lasnamägi, Uhaku, Kukruse and Idavere regional stages $\left(\mathrm{C}_{\mathrm{I}} \mathrm{b}\right.$ $\mathrm{C}_{\mathrm{III}}$ ) greenish marl was deposited in the Bothnian Sea before the regression in the eastern Baltic Sea during the Jõhvi, Keila and Oandu regional stages $\left(\mathrm{D}_{\mathrm{I}}-\mathrm{D}_{\mathrm{III}}\right)$ (Männil 1966). According to Jaanusson (1982), the sea covered Dalarna all the period from Lasnamägi to as late as Porkuni, from middle to late Ordovician. The second Ordovician transgression in Europe took place during Llanvirn (Fortey 1984), i.e. during the transition from Aseri to Lasnamägi. The results of the present study (Fig. 9) support this view.

During the Caradoc, one of the widest Ordovician transgressions of the world also covered most of the epeiric seas (Fortey 1984). It was in the beginning of this transgression (Idavere and Jõhvi regional stages) that the Lappajärvi area was covered by the sea. This view is in accordance with the results of this study. 


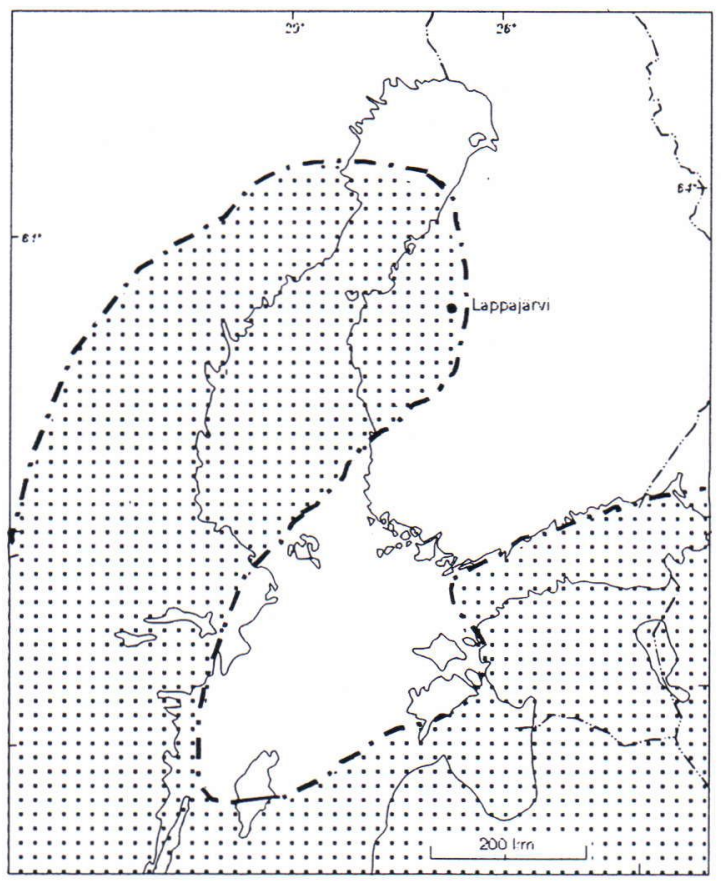

Fig. 8. Extent of the Lower Ordovician Baltic Sea (Billingen Regional Stage).

ACKNOWLEDGEMENTS: The limestone erratic boulders were collected by Phil.lic. Aimo Kejonen in 1989. Drs Dorothy Guy-Olsson, John Richardson and Milada Vavrdová commented the unknown spores. Drs Kaarina Sarmaja-Korjonen and Martti Lehtinen read and commented the manusc-

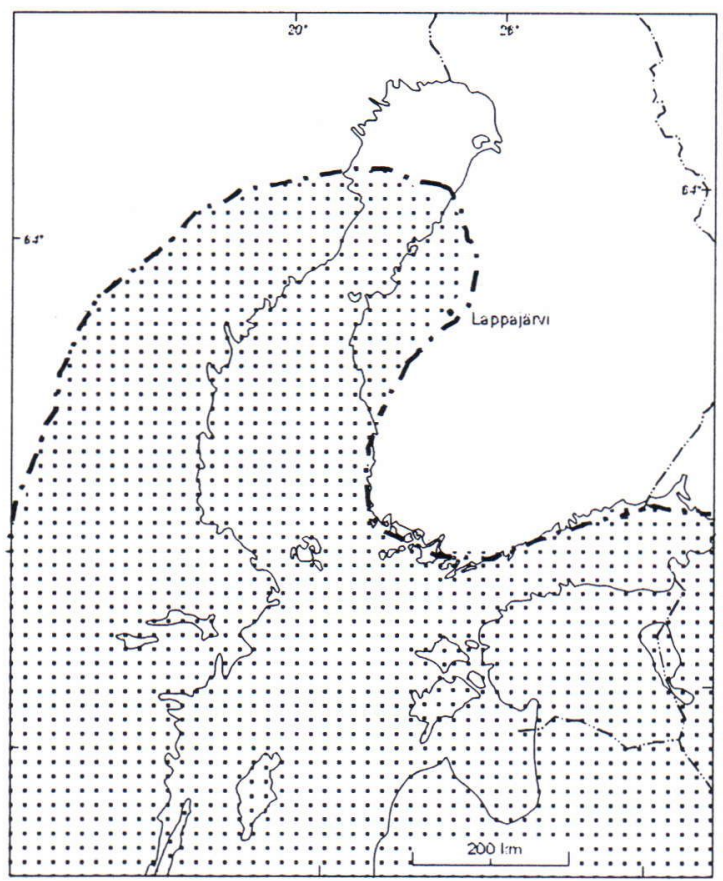

Fig. 9. Extent of the Middle Ordovician Baltic Sea (Aseri/Lasnamägi transition and Idavere/Jõhvi transition).

ript and Phil.lic. Tuija Jantunen drew some of the figures. Professors Joakim Donner and Pentti Alhonen refereed the manuscript. The English language was checked by Margot Whiting. I thank all of them cordially. 
Table la. The total number of Cambrian acritarch specimens, and percentual amounts of $\mathrm{CaCO}_{3}$ in mudstone in the Kärnänsaari drillcore DC304, Lappajärvi.

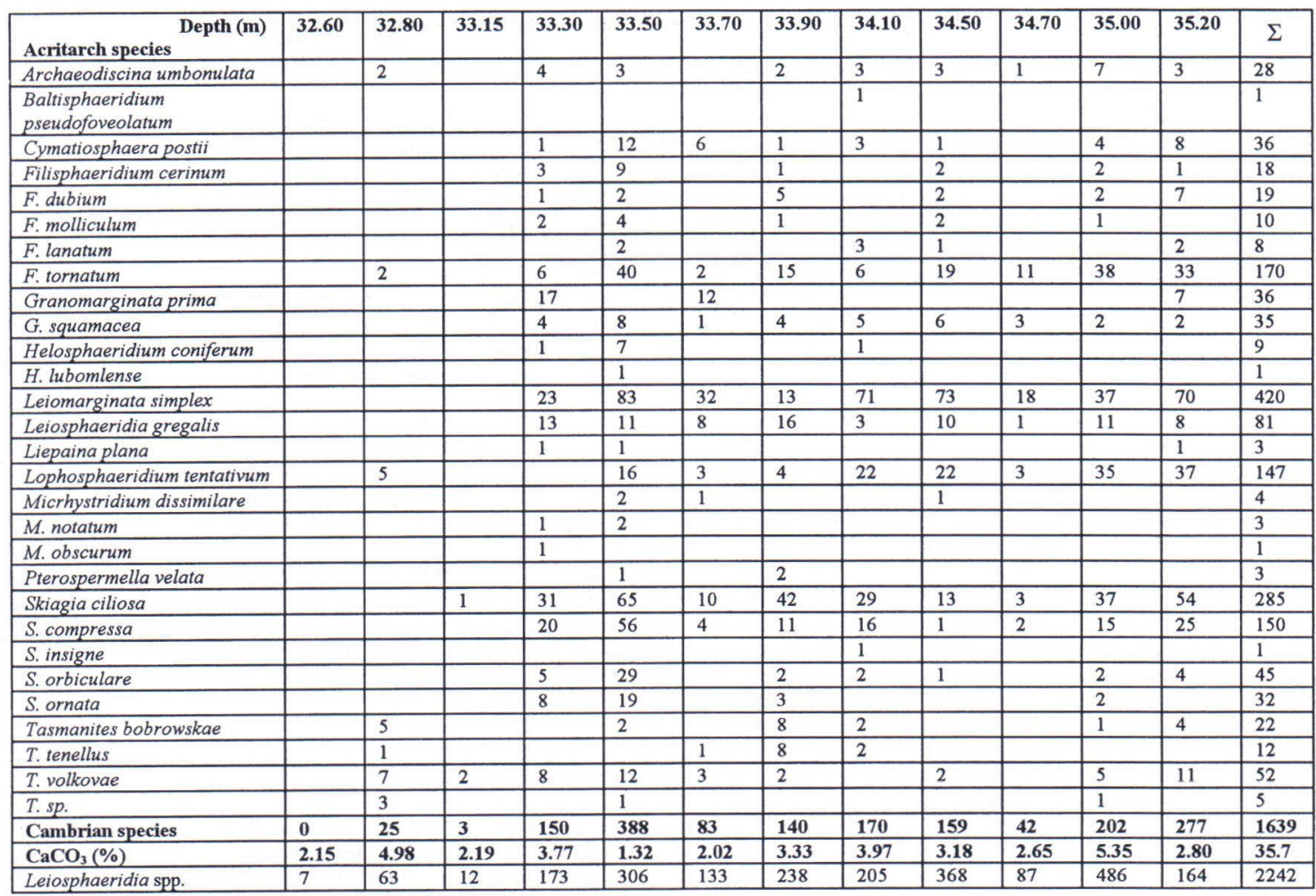


Table $1 b$. The total number of Ordovician acritarch specimens, and unknown spores in the Kärnänsaari drillcore DC304, Lappajärvi.

\begin{tabular}{|c|c|c|c|c|c|c|c|c|c|c|c|c|c|}
\hline $\begin{array}{l}\text { Depth (m) } \\
\text { Acritarch species }\end{array}$ & 32.60 & 32.80 & 33.15 & 33.30 & 33.50 & 33.70 & 33.90 & 34.10 & 34.50 & 34.70 & 35.00 & 35.20 & $\Sigma$ \\
\hline Baltisphaeridium accinctum & & & & & 1 & & & & & & & & 1 \\
\hline B. anneliae & & & & 1 & 1 & 2 & & 2 & 1 & & & & 7 \\
\hline B. constrictum & & & & & 1 & 1 & 1 & & & & & & 3 \\
\hline B. dasos & & & & & 1 & & & & & & & & 1 \\
\hline B. flexuosum & & & & 2 & & & & & & & & & 2 \\
\hline B. hirsutoides & & & & & 6 & 2 & 4 & 1 & & 1 & 4 & 7 & 25 \\
\hline B. ingerae & & & & & & & & 1 & & & & & 1 \\
\hline B. latiradiatum & & & & & & & & & & & & 1 & 1 \\
\hline B. longispinosum & & & & & 2 & & & & 1 & & 1 & 2 & 6 \\
\hline B. microspinosum & & & & & & 1 & & & & & & & 1 \\
\hline B. multiechinatum & & & & & & & & 1 & & & & & 1 \\
\hline B. multipilosum & & & & & 1 & & & & & & & & 1 \\
\hline B. nanninum & & 2 & & & 1 & & 2 & 2 & & & & & 7 \\
\hline B. oligopsakium & & & & & & & & & & & 1 & & 1 \\
\hline B. parvigranosum & & & & & & & & 1 & & & & & 1 \\
\hline B. pauciverrucosum & & & & & & & 1 & & & & & & 1 \\
\hline B. pseudocalicispinum & & & & & & & 1 & 1 & & & & & 2 \\
\hline B. pustulatum & & & & & 1 & & & & & & & & 1 \\
\hline B. trabeculaespinae & & & & 1 & & & & & & & & & 1 \\
\hline B. tranvikensis & & 4 & & & & & & & & 3 & 1 & & 8 \\
\hline B. $s p$ /Ordovicidium $s p$. & 3 & 9 & 4 & 2 & 2 & & 2 & 3 & 1 & & 3 & 6 & 35 \\
\hline Cheleutochroa venosa & & & & & & & & & & & & 1 & 1 \\
\hline Comasphaeridium filosum & & 1 & & & 1 & & 3 & 1 & & & & & 6 \\
\hline Filisphaeridium henryi & & & & 1 & & & & & & & & & 1 \\
\hline $\begin{array}{l}\text { Goniosphaeridium } \\
\text { mochtiensis }\end{array}$ & & 2 & & 3 & 1 & 2 & 2 & & 1 & 2 & & 1 & 14 \\
\hline G.sp. & & & & 5 & & 1 & & & & & & & 6 \\
\hline $\begin{array}{l}\text { Lophosphaeridium } \\
\text { citrinipeltatum }\end{array}$ & & & & & & & 1 & & 4 & 1 & 1 & & 7 \\
\hline L. disparipelliculum & & & & 2 & & & & & & & & & 2 \\
\hline L. papillatum & & 3 & & 6 & 5 & & 4 & 12 & & & & & 30 \\
\hline L. pilosum & & & & & & & & & & & 1 & & 1 \\
\hline $\begin{array}{l}\text { Martinisphaeridium } \\
\text { bifurcatum }\end{array}$ & & & & & & & 1 & 1 & & & & & 2 \\
\hline M. bipalmatum & & & & & & & & & 1 & & 1 & & 2 \\
\hline M. parvipinnatum & & & & & 1 & & & & & & & & 1 \\
\hline M. raplaense & & & & 1 & & & & & & & 1 & 1 & 3 \\
\hline $\begin{array}{l}\text { Micrhystridium } \\
\text { nannacanthum }\end{array}$ & & & & & & & & & 6 & & 3 & & 9 \\
\hline M. stellatum & & & & & 1 & & 1 & & & & 1 & & 3 \\
\hline $\begin{array}{l}\text { Multiplicisphaeridium } \\
\text { alloteaui }\end{array}$ & & & & & & & 2 & 7 & 5 & & & 2 & 16 \\
\hline M. fissile & & & & 2 & 7 & & & 1 & 3 & & & 3 & 16 \\
\hline M. irregulare & & & & & 3 & & & & & & & & 3 \\
\hline Ordovicidium elegantulum & & 5 & & & 3 & 1 & & 2 & & & 1 & & 12 \\
\hline O. grotlingboensis & & & & & 1 & & 1 & & & & 1 & 1 & 4 \\
\hline O. heteromorphicum & & 2 & & 1 & 1 & & 1 & & & & 2 & & 7 \\
\hline O. nudum & & & & & & & 3 & & & & 2 & & 5 \\
\hline $\begin{array}{l}\text { Ortohosphaeridium } \\
\text { densiverrucosum }\end{array}$ & & & & 1 & & & & & 1 & & & & 2 \\
\hline O. insculptum & & & & & 2 & 1 & 3 & & & & & & 6 \\
\hline O. vibrissiferum & & & & & & & & & & & & 1 & 1 \\
\hline O. sp. & & & & & & & & & & & 1 & & 1 \\
\hline Peteinosphaeridium eximum & & & & & & & & 2 & & & & & 2 \\
\hline Polygonium pellicidum & & & & & 4 & 1 & & 1 & 2 & 1 & 1 & 4 & 14 \\
\hline Rhopaliophora sp. & & & & & 1 & & & & & & & & 1 \\
\hline Tasmanites verrucosus & & & & 1 & & & 2 & & & & & 2 & 5 \\
\hline Tylotopalla varipinnosum & & & & & & & 1 & & & & 1 & & 2 \\
\hline Veryhachium irroratum & & & & 1 & 4 & & 15 & 5 & 1 & & 17 & 2 & 45 \\
\hline V. lairdi & & & & & 1 & & & & & & & & 1 \\
\hline V. reductum & & & & 1 & & & & 2 & & 3 & 2 & & 8 \\
\hline V. trispinosum & & & & 3 & 5 & 4 & 5 & 18 & 12 & 3 & 5 & & 55 \\
\hline V. trisulcum & & & & 10 & & & 5 & & 9 & 4 & 15 & 13 & 56 \\
\hline V.sp. & & 1 & & & & & & & & & & & 1 \\
\hline Ordovician species & 3 & 29 & 4 & 44 & 57 & 16 & 61 & 64 & 48 & 18 & 66 & 47 & 457 \\
\hline Spore sp. 1 & & & & 7 & 13 & 5 & 18 & 11 & 6 & 3 & 4 & 7 & 74 \\
\hline Spore sp. 2 & & & & & & & & & 1 & & & & 1 \\
\hline
\end{tabular}


Table 2. Living ranges of the Lower and Middle Cambrian acritarchs in the Baltic area. (References: Hagenfeldt 1989b, c, Mozydlowska 1989 with their references). Legend: $\$$ a living range to earlier than the Talsy Regional Stage. Upper Cambrian assemblage in the Baltic area differs greatly from the earlier ones (cf. Paalits 1995).

\begin{tabular}{|c|c|c|c|c|c|}
\hline & Lower & Cambrian & & Middle & Cambrian \\
\hline $\begin{array}{l}\text { Age } \\
\text { Acritarch species }\end{array}$ & Talsy & Vergale & Rausve & Kibartai & Paneriai \\
\hline Archaeodiscina umbonulata & 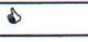 & $*$ & * & $*$ & \\
\hline Baltisphaeridium pseudofoveolatum & & & & $*$ & \\
\hline Cymatiosphaera postii & $*$ & $*$ & $*$ & $*$ & * \\
\hline Filisphaeridium cerinum & $\$$ & * & * & & \\
\hline F. dubium & $*$ & * & * & & \\
\hline F. molliculum & $*$ & * & & & \\
\hline F. lanatum & 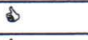 & $*$ & $*$ & $*$ & \\
\hline F. tornatum & $\$$ & $*$ & * & $*$ & $*$ \\
\hline Granomarginata prima & 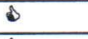 & $*$ & $*$ & $*$ & $*$ \\
\hline G. squamacea & $\$$ & * & $*$ & $*$ & $*$ \\
\hline Helosphaeridium coniferum & $*$ & $*$ & & & \\
\hline H. lubomdense & $*$ & $*$ & $*$ & & \\
\hline Leiomarginata simplex & $D$ & $*$ & $*$ & $*$ & $*$ \\
\hline Leiosphaeridia gregalis & $*$ & * & $*$ & $*$ & $*$ \\
\hline Liepaina plana & & & $*$ & $*$ & $*$ \\
\hline Lophosphaeridium tentativum & 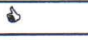 & $*$ & $*$ & $*$ & $*$ \\
\hline Micrhystridium dissimilare & $*$ & $*$ & $*$ & $*$ & $*$ \\
\hline M. notatum & & & $*$ & * & * \\
\hline M. obscurum & $*$ & $*$ & $*$ & $*$ & $*$ \\
\hline Pterospermella velata & $\Delta$ & $*$ & $*$ & $*$ & $*$ \\
\hline Skiagia ciliosa & $*$ & $*$ & $*$ & $*$ & \\
\hline S. compressa & $*$ & * & * & * & \\
\hline S. insigne & $*$ & $*$ & $*$ & * & * \\
\hline S. orbiculare & $*$ & $*$ & $*$ & & \\
\hline S. ornata & $*$ & $*$ & $*$ & & \\
\hline Tasmanites bobrowskae & 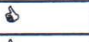 & $*$ & $*$ & $*$ & $*$ \\
\hline T. tenellus & $\$$ & $*$ & $*$ & & \\
\hline T. volkovae & $*$ & $*$ & * & $*$ & * \\
\hline
\end{tabular}


Table 3. Living ranges of the Ordovician acritarchs in the Baltic area. Legend: $\$=$ a living range extending to the Vormsi Regional Stage $\left(F_{l} b\right)$ or later. References: Uutela and Tynni (1991) and references herein; ${ }^{++}$preliminary results from the Männamaa material, Hiiumaa, Estonia.

\begin{tabular}{|c|c|c|c|c|c|c|c|c|c|c|c|c|}
\hline $\begin{array}{l}\text { Estonian regional stages } \\
\text { Acritarch species }\end{array}$ & $\mathbf{B}_{\text {II }}$ & $\mathbf{B}_{\text {III }}$ & $\mathbf{C}_{\mathrm{I}} \mathbf{a}$ & $\mathbf{C}_{\mathrm{I}} \mathbf{b}$ & $\mathrm{C}_{\mathrm{I}} \mathrm{c}$ & $\mathbf{C}_{\text {II }}$ & $\mathbf{C}_{\mathrm{II}}$ & $\mathbf{D}_{\mathrm{I}}$ & $\mathbf{D}_{\text {II }}$ & $\mathbf{D}_{\text {III }}$ & $\mathbf{E}$ & $\mathbf{F}_{\mathrm{I}} \mathbf{a}$ \\
\hline Baltisphaeridium accinctum & $*$ & $*$ & * & * & $*$ & * & & & & & & \\
\hline B. anneliae & & $*$ & * & * & $*$ & $*$ & & & & & & \\
\hline B. constrictum ${ }^{++}$ & & & & * & $*$ & * & * & & & & & \\
\hline B. dasos & & & & * & $*$ & $*$ & * & $*$ & * & * & * & $\beta$ \\
\hline B. flexuosum & & $*$ & * & * & * & $*$ & & & & & & \\
\hline B. hirsutoides & $*$ & $*$ & * & * & * & * & * & * & * & $*$ & * & 8 \\
\hline B. ingerae & * & $*$ & * & * & $*$ & * & & & & & & \\
\hline B. latiradiatum & & $*$ & * & * & $*$ & $*$ & $*$ & $*$ & $*$ & & & \\
\hline B. longispinosum & $*$ & * & * & * & * & * & * & $*$ & $*$ & * & * & $P$ \\
\hline B. microspinosum & * & $*$ & $*$ & * & $*$ & * & $*$ & $*$ & $*$ & $*$ & * & $\beta$ \\
\hline B. multiechinatum & * & $*$ & * & * & * & * & $*$ & & & & & \\
\hline B. multipilosum & * & $*$ & * & * & $*$ & * & & & & & & \\
\hline B. nanninum & & $*$ & $*$ & * & $*$ & * & $*$ & * & * & $*$ & & \\
\hline B. oligopsakium & & $*$ & * & $*$ & $*$ & $*$ & $*$ & * & $*$ & * & $*$ & $\beta$ \\
\hline B. parvigranosum & & & & * & $*$ & * & $*$ & * & $*$ & * & * & $\beta$ \\
\hline$B$ pauciverrucosum & $*$ & $*$ & * & $*$ & $*$ & * & * & $*$ & $*$ & $*$ & * & \\
\hline B. pseudocalicispinum & * & $*$ & * & * & $*$ & * & $*$ & * & $*$ & * & * & $\beta$ \\
\hline B. pustulatum & & & * & $*$ & $*$ & * & $*$ & * & $*$ & * & * & $\beta$ \\
\hline B. trabeculaespinae & & & & & & & * & * & $*$ & $*$ & $*$ & $\beta$ \\
\hline B. tranvikensis & $*$ & $*$ & * & * & $*$ & & & & & & & \\
\hline Cheleutochroa venosa & & & & & & & & * & * & * & $*$ & $\beta$ \\
\hline Comasphaeridium filosum & * & $*$ & * & * & * & * & $*$ & * & $*$ & & & \\
\hline Filisphaeridium henryi & $*$ & $*$ & * & $*$ & $*$ & * & $*$ & $*$ & * & * & * & $\beta$ \\
\hline Goniosphaeridium mochtiensis & & $*$ & * & * & & & & & & & & \\
\hline Lophosphaeridium citrinipeltatum & * & $*$ & $*$ & * & * & * & $*$ & $*$ & * & * & $*$ & $\beta$ \\
\hline L. disparipelliculum & & & & * & * & * & * & $*$ & * & * & $*$ & $\beta$ \\
\hline L. papillatum & * & $*$ & $*$ & $*$ & $*$ & $*$ & $*$ & $*$ & * & $*$ & $*$ & $\beta$ \\
\hline L. pilosum & $*$ & $*$ & * & * & * & * & * & * & * & * & $*$ & $\beta$ \\
\hline Martinsphaerisium bifurcatum & $*$ & $*$ & * & $*$ & * & * & $*$ & $*$ & * & * & $*$ & 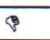 \\
\hline M. bipalmatum & & & * & $*$ & $*$ & $*$ & $*$ & $*$ & $*$ & $*$ & $*$ & $\beta$ \\
\hline M. parvipinnatum & & * & $*$ & $*$ & * & * & * & * & * & * & $*$ & 8 \\
\hline M. raplaense & & * & $*$ & $*$ & * & $*$ & $*$ & $*$ & * & $*$ & $*$ & $\beta$ \\
\hline Micrhystridium nannacanthum & $*$ & $*$ & $*$ & $*$ & * & * & * & * & * & * & $*$ & $\beta$ \\
\hline M. stellatum & & $*$ & $*$ & $*$ & * & * & $*$ & $*$ & * & * & $*$ & $\beta$ \\
\hline M. varipinnosum & $*$ & $*$ & $*$ & $*$ & * & $*$ & $*$ & $*$ & * & $*$ & $*$ & $P$ \\
\hline Multiplicisphaeridium alloteaui & $*$ & $*$ & $*$ & $*$ & * & $*$ & $*$ & $*$ & * & $*$ & $*$ & $\beta$ \\
\hline M. fissile & $*$ & $*$ & $*$ & $*$ & * & * & $*$ & * & * & $*$ & $*$ & $\beta$ \\
\hline M. irregulare & & $*$ & $*$ & $*$ & $*$ & $*$ & $*$ & * & * & $*$ & $*$ & $\beta$ \\
\hline Ordovicidium elegantulum & & & & & * & * & * & * & * & * & $*$ & $\beta$ \\
\hline O. grotlingboensis & & & & $*$ & * & * & $*$ & * & * & $*$ & $*$ & 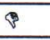 \\
\hline O. heteromorphicum & & & $*$ & $*$ & * & $*$ & $*$ & * & * & $*$ & $*$ & $\beta$ \\
\hline O. nudum & & & & $*$ & * & * & $*$ & * & * & $*$ & $*$ & $\beta$ \\
\hline Orthosphaeridium densiverrucosum & & & $*$ & $*$ & $*$ & $*$ & $*$ & * & * & $*$ & & \\
\hline O. insculptum & & & $*$ & $*$ & * & * & $*$ & * & * & $*$ & $*$ & $\beta$ \\
\hline O. vibrissiferum & & & $*$ & $*$ & * & * & $*$ & * & * & $*$ & $*$ & $\beta$ \\
\hline Peteinosphaeridium eximum ${ }^{++}$ & $*$ & $*$ & $*$ & & & & & & & & & \\
\hline Polygonium pellicidum & & $*$ & $*$ & $*$ & $*$ & * & $*$ & * & $*$ & $*$ & $*$ & $*$ \\
\hline Tasmanites verrucosus & & & & & & * & $*$ & $*$ & * & $*$ & $*$ & $P$ \\
\hline Veryhachium irroratum & & & & & & & $*$ & $*$ & * & $*$ & $*$ & 8 \\
\hline V. lairdi & & $*$ & $*$ & $*$ & * & * & $*$ & * & * & $*$ & * & 9 \\
\hline V. reductum & & & & & * & $*$ & $*$ & * & * & & & \\
\hline V. trispinosum & & $*$ & $*$ & $*$ & $*$ & $*$ & $*$ & $*$ & * & $*$ & $*$ & $*$ \\
\hline V. trisulcum & & & & & $*$ & $*$ & $*$ & $*$ & $*$ & & & \\
\hline
\end{tabular}


Table 4. Living ranges and total numbers of the Ordovician species found in the Hietakangas erratic boulder. Legend: = a living range extending to the Vormsi Regional Stage $\left(F_{l} b\right)$ or later. References: Uutela and Tynni (1991, and preliminary results from the Männamaa material, Hiiumaa, Estonia.

\begin{tabular}{|c|c|c|c|c|c|c|c|c|c|c|c|c|}
\hline $\begin{array}{l}\text { Estonian regional stage } \\
\text { Acritarch species }\end{array}$ & $\mathbf{B}_{\text {II }}$ & $\mathbf{B}_{\text {II }}$ & $\mathbf{C}_{\mathrm{I}} \mathbf{a}$ & $\mathbf{C}_{\mathrm{I}} \mathrm{b}$ & $\mathrm{C}_{\mathrm{I}} \mathrm{c}$ & $\mathbf{C}_{\text {II }}$ & $\mathbf{C}_{\text {III }}$ & $\mathbf{D}_{\mathbf{I}}$ & $\mathbf{D}_{\text {II }}$ & $\mathbf{D}_{\text {III }}$ & $\mathbf{E}$ & $\Sigma$ \\
\hline Baltisphaeridium esthonicum & $*$ & * & $*$ & $*$ & & & & & & & & 9 \\
\hline B. flexuosum & $*$ & $*$ & $*$ & $*$ & * & * & $*$ & $*$ & & & & 1 \\
\hline B. hirsutoides & $*$ & $*$ & * & $*$ & * & * & $*$ & * & * & * & 9 & 3 \\
\hline B. longispinosum & $*$ & $*$ & $*$ & $*$ & $*$ & * & $*$ & * & $*$ & $*$ & 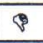 & 1 \\
\hline B. parvigranosum & & & & $*$ & * & $*$ & $*$ & $*$ & * & $*$ & 9 & 4 \\
\hline B. pauciverrucosum & * & * & * & $*$ & * & * & $*$ & * & * & $*$ & & 1 \\
\hline B. pseudocalicispinum & $*$ & $*$ & $*$ & * & * & * & * & $*$ & * & $*$ & $\beta$ & 1 \\
\hline B. trichophorum & * & * & * & * & * & * & & & & & & 2 \\
\hline Gyalorhethium sp. & & & & & & & & & & & & 1 \\
\hline Lophosphaeridium citrinipeltatum & * & * & * & $*$ & * & * & $*$ & $*$ & * & * & $\rho$ & 1 \\
\hline L. papillatum & * & * & * & * & * & * & * & * & * & * & 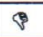 & 1 \\
\hline Micrhystridium nannacanthum & $*$ & $*$ & $*$ & $*$ & * & * & $*$ & $*$ & * & $*$ & $\phi$ & 3 \\
\hline Martinsphaeridium raplaense & & * & * & $*$ & * & * & $*$ & $*$ & * & $*$ & $p$ & 5 \\
\hline Ordovicidium grotlingboensis & & & & $*$ & $*$ & * & $*$ & $*$ & $*$ & $*$ & 9 & 2 \\
\hline O. heteromorphicum & & & * & $*$ & * & * & $*$ & $*$ & * & $*$ & $\varphi$ & 2 \\
\hline O. nudum & & & & $*$ & * & * & $*$ & $*$ & $*$ & $*$ & 9 & 4 \\
\hline Solisphaeridium inaffectum & & $*$ & $*$ & $*$ & * & * & $*$ & * & * & $*$ & 9 & 1 \\
\hline Veryhachium trispinosum & & * & $*$ & $*$ & $*$ & $*$ & $*$ & * & * & $*$ & * & 1 \\
\hline
\end{tabular}




\section{REFERENCES}

Bergman, L. 1982. Clastic dykes in the Alland Islands, SW Finland and their origin. Geological Survey of Finland, Bulletin 317, 7-33.

Eriksson, B., Grönlund, T. \& Uutela, A. (in print). Biostratigraphy of the Eemian and Weichselian sediments at Mertuanoja, Ostrobothnia, western Finland. Boreas 28:2.

Eskola, P. 1927. Suomen "tulivuorijärvet" Jänisjärvi ja Lappajärvi. Summary: Lakes Jänisjärvi and Lappajärvi. The "volcano lakes" of Finland. Terra 39, 1-8.

Fortey, R.A. 1984. Global earlier Ordovician transgressions and regressions and their biological implications. In: Bruton, D.L. (ed.) Aspects of the Ordovician System. Palaeontological Contribution from the University of Oslo, No. 295, 37-50.

Geological Survey of Finland 1986. Striations, eskers and ice-marginal formations 1: 4000 000. Geological Survey of Finland. Department of Quaternary Geology. (Map).

Hagenfeldt, S. 1989a. Lower and Middle Cambrian acritarchs from the Baltic Depression and south-central Sweden, taxonomy, stratigraphy and palaeogeographic reconstruction. Doctoral thesis, Department of Geology, University of Stockholm, $32 \mathrm{pp}$.

Hagenfeldt, S. 1989b. Lower Cambrian acritarchs from the Baltic Depression and south-central Sweden, taxonomy and biostratigraphy. Stockholm Contributions in Geology $41,1-176$.

Hagenfeldt, S. 1989c. Middle Cambrian acritarchs from the Baltic Depression and south-central Sweden, taxonomy and biostratigraphy. Stockholm Contributions in Geology $41,177-250$.

Hansen, K. 1945. The Middle and Upper Cambrian sedimentary rocks of Bornholm. Danmarks Geologiske Undersøgelse RII, $72.81 \mathrm{p}$.

Hessland, I. 1955. Studies in the lithogenesis of the Cambrian and basal Ordovician of the Böda Hamn sequence of strata. Boring through the Cambrian and Ordovician strata at Böda Hamn, Öland II. Bulletin of the Geological Institution of the University of Upsala. XXXV (1953-1955), 35-111.

Jaanusson, V. 1972. Constituent analysis of an Ordovician limestone from Sweden. Lethaia 5, 217-237.

Jaanusson, V. 1982. Introduction to the Ordovician of Sweden. In: Bruton, D.L. \& Williams, S.H. (eds.) Field excursion guide IV International Symposium on the Ordovician System. Palaeontological Contributions from the University of Oslo 279, 1-10.

Jessberger, E.K. \& Reimold, W.U. 1980. A late Cretaceous ${ }^{40} \mathrm{Ar}-{ }^{39} \mathrm{Ar}$ age for the Lappajärvi impact crater, Finland. Journal of Geophysics 48, 57-59.

Kujansuu, R. \& Uutela, A. 1997. Palaeozoic acritarchs from Kauhajoki till covered silt formation. In: Autio, S. (ed.) Geological Survey of Finland, Current Research 19951996. Geological Survey of Finland, Special Paper 23, 93-98.

Kulling, O. 1926. Nya data till Ålands geologi II. Den ny- upptäckta östersjökalken i Lumparfjärden. Geologiska Förening i Stockholm Förhandlingar 48, 503-509.

Lindström, M. 1979. Diagenesis of Lower Ordovician hardgrounds in Sweden. Geologica et Palaeontologica $13,9-30$.

Löfgren, A. 1985. Early Ordovician conodont biozonation at Finngrundet, south Bothnian Bay, Sweden. (Geology of the southern Bothnian Sea, Part III). Bulletin of the Geological Institutions of the University of Uppsala, New Series 10, 135-142.

Männil, R. 1966. Evolution of the Baltic basin during Ordovician. Tallinn: Eesti NSV Teaduste Akadeemia Geoloogia Instituut. 199 p. (in Russian with English summary)

Martinsson, A. 1956. Neue Funde kambrischer Gänge und ordovizischer Geschiebe im südwestlichen Finnland. Bulletin of the Geological Institutions of the University of Uppsala XXXVI, 79-105.

Mens, K., Bergström, J. \& Lendzion, K. 1987. The Cambrian System on the East European Platform. Correlation Chart and Explanatory Notes. Tallinn: Valgus. $119 \mathrm{p}$.

Moczydlowska, M. 1991. Acritarch biostratigraphy of the Lower Cambrian and the Precambrian-Cambrian boundary in southeastern Poland. Fossil and Strata 29. 127 p.

Mölder, K. 1948. Die Verbreitung der Dacitblöcke in der Moräne in der Umgebung des Sees Lappajärvi. Bulletin de la Commission géologique de Finlande 142, 45-52.

Nõlvak, J. 1997. The Ordovician of Estonia (Table 7). In: Raukas, A. \& Teedumäe, A. (eds.) Geology and mineral resources of Estonia. Tallinn: Estonian Academy Publishers, 54-55.

Öpik, A.A. 1956. Cambrian (Lower Cambrian) of Estonia. El sistema Cámbrico, su paleogeografía y el problema de su base. Symposium I, Part I: Europa, Africa, Asia. XX Congreso Geólogico Internacional, XX Sesión, México, 97-126.

Paalits, I. 1995. Acritarchs from the Cambrian - Ordovician boundary beds at Tönismägi, Tallinn, North Estonia. Proceedings of Estonian Academy of Sciences, Geoloogia 44, 87-96.

Pesonen, L.J., Pipping, F. \& Halls, H.C. 1984. Paleomagnetic study of the Lake Lappajärvi impact crater, western Finland. Terra Cognita 4, 371.

Põlma, L. 1972. Skeletal debris content and composition in the sediments of the northern facial belt of the East Baltic: Ordovician (Rapla boring). Eesti NSV Teaduste Akadeemia Toimetised 21. Köide Keemia Geoloogia $\mathrm{Nr}$ 4, 326-332. (in Russian).

Richardson, J.B. 1996. Chapter 18A. Lower and middle Palaeozoic records of terrestrial palynomorphs. In: Jansonius, J. \& McGregor, D.E. (eds.) Palynology, principles and applications. American Association of Stratigraphic Palynologists Foundation, Vol 2, 555-574.

Simonen, A. 1956. Cambrian sediments in Finland. El sistema Cámbrico, su paleogeografía y el problema de su base. Symposium I, Part I: Europa, Africa, Asia. XX Congreso Geólogico Internacional, XX Sesión, México, 91-95. 
Simonen, A. \& Kouvo, O. 1955. Sandstones in Finland. Bulletin de la Commission géologique de Finlande 168, 57-87.

Svensson, N.-B. 1968. Lake Lappajärvi, Central Finland: a possible meteorite impact structure. Nature 217, 438.

Thorslund, P. 1960. The Cambro-Silurian. In: Hessland, I. (ed.) Description to accompany the map of the pre-Quaternary rocks of Sweden. Sveriges Geologiska undersökning, Series Ba 16, 96-110.

Thorslund, P. \& Axberg, S. 1979. Geology of the Bothnian Sea. Part 1. Bulletin of the Geological Institutions of the University of Uppsala. New Series 8, 35-62.

Tjernvik, T.E. \& Johansson, J.V. 1980. Description of the upper portion of the drill-core from Finngrundet in the South Bothnian Bay. Bulletin of the Geological Institutions of the University of Uppsala. New Series 8, 173204.

Tynni, R. 1974. Microfossils in a specimen of Cambrian (?) sandstone from Karstula, Central Finland. Bulletin of the Geological Society of Finland 46, 9-13.

Tynni, R. 1978. Lower Cambrian fossils and acritarchs in the sedimentary rocks of Söderfjärden, western Finland. Geological Survey of Finland, Bulletin 297, 41-63.

Tynni, R. 1982a. New results of studies on the fossils in the Lower Cambrian sediment deposit of Söderfjärden. Bulletin of the Geological Society of Finland 54, 5768.

Tynni, R. 1982b. On Paleozoic microfossils in clastic dykes in the Aland Islands and in the core samples of Lumparn. Geological Survey of Finland, Bulletin 317, 35-115.

Uutela, A. 1983. Field investigations in the area of the Muhos formation 25.5.-23.6.1983. Geological Survey of Finland, Quaternary Department. Report P 13.5.023. 38 p + 31 app. (in Finnish).
Uutela, A. 1989. Age and dispersal of sedimentary erratics on the coast of southwestern Finland. Geological Survey of Finland, Bulletin 349. 100 p.

Uutela, A. 1990. Proterozoic microfossils from the sedimentary rocks of the Lappajärvi impact crater. Bulletin of the Geological Society of Finland 62, 115-121.

Uutela, A. \& Tynni, R. 1991. Ordovician acritarchs from the Rapla borehole, Estonia. Geological Survey of Finland, Bulletin 353. 135 p, XXX Pl.

Vaarma, M. \& Pipping, F. 1997. Alajärven ja Evijärven kartta-alueiden kallioperä. Summary: Pre-Quaternary rocks of the Alajärvi and Evijärvi map-sheet areas. Geological map of Finland 1: 100 000. Explanation to the maps of Pre-Quaternary rocks. Sheets 2313 and 2314. Geological Survey of Finland. 83 p.

Vidal, G. 1988. A palynological preparation method. Palynology 12, 215-220.

Vavrdová, M. 1984 Some plant microfossils of possible terrestrial origin from the Ordovician of Central Bohemia. Vestnik Ustredniho ustavu geologickeho 59, 165170.

Volkova, N.A. 1976. On finds of Precambrian spores with a tetrad scar. Paleontologiya. Morskaya geologiya. Moscow: Nauka, 14-18. (in Russian)

Wannäs, K. 1989. Seismic stratigraphy and tectonic development of the Upper Proterozoic to Lower Palaeozoic of the Bothnian Bay, Baltic Sea. Acta Universitatis Stockholmensis, Stockholm Contributions in Geology 40, 83-168.

Winterhalter, B. 1972. On the geology of the Bothnian Sea, an epeiric sea that has undergone Pleistocene glaciation. Geological Survey of Finland, Bulletin 258. 66 p. 